\title{
PEMODELAN SISTEM INFORMASI PENJUALAN BARANG PADA CV. CLEVER KIDS DENGAN MENGGUNAKAN METODOLOGI BERORIENTASI OBYEK
}

\author{
Arif Munandar ${ }^{1)}$, Lis Suryadi ${ }^{2}$ \\ ${ }^{1}$ Sistem Informasi, Fakultas Teknologi Informasi, Universitas Budi Luhur \\ 1,2 Jl. Raya Ciledug, Petukangan Utara, Kebayoran Lama, Jakarta Selatan 12260 \\ E-mail: ariefmunandar63@gmail.com ${ }^{1)}$, $\underline{\text { lis.suryadi@budiluhur.ac.id }}{ }^{2}$
}

\begin{abstract}
Abstrak
CV Clever Kids adalah perusahaan yang bergerak dalam bidang penjualan pakaian jadi. Saat ini sistem yang digunakan oleh CV Clever Kids masih secara manual sehingga file mudah rusak dan hilang. Kemudian di setiap departemen yang ada di CV Clever Kids belum terkelola dengan baik sehingga dalam setiap proses bisnis tidak bekerja secara efektif. Masalah lain yang menjadi kendala sering terjadi kesalahan dalam pencatatan data dikarenakan tidak adanya data surat jalan, tidak adanya data retur, tidak adanya data stok barang terubdate, dan minimnya data laporan barang. Tujuan dari penelitian ini adalah menggunakan teknologi komputer untuk menggantikan sistem manual. Rapid Application Design (RAD) adalah sistem pengembangan yang peneliti gunakan mencangkup tahapan perencanaan, analisa, desain, implementasi, pengujian, dan pemeliharaan. Pada tahap analisis perancangan sistem menggunakan pendekatan berorientasi objek untuk analisis (OOA). Pada tahap desain, menggunakan desain berorientasi objek (OOD) dan alat yang digunakan adalah Unified Modeling Language (UML). Bahasa pemograman yang digunakan adalah Visual Basic.Net dan Mysql sebagai alat penyimpan datanya. Dengan adanya tetnologi komputer ini pemilik dapat mengetahui data surat jalan, data retur, data stok barang terupdate dan sudah tersedianya laporan transaksi penjualan yang dibutuhkan pemilik.
\end{abstract}

Kata kunci: sistem, informasi, penjualan, Berorientasi, Cv.CleverKids.

\section{PENDAHULUAN}

Perkembangan dunia teknologi yang semakin pesat dewasa ini, membuat berbagai perusahaan menggunakannya untuk meningkatkan kinerja dalam mencapai tujuan yang diinginkan. Salah satu teknologi informasi yang digunakan adalah komputer, dimana komputer itu sendiri merupakan perangkat elektronik yang terdiri dari beberapa komponen yang saling bekerja sama saling membentuk sebuah sistem kerja yang dapat menjalankan pekerjaan secara otomatis berdasar urutan instruksi maupun program yang telah diberikan kepadanya, sehingga dapat menciptakan suatu informasi berdasarkan program dan data yang ada. Peranan teknologi komputer sebagai alat pengolahan data sangat mendukung beragam kegiatan baik individu maupun organisasi. Selain itu, teknologi informasi juga dapat mempermudah dalam pencarian data, penyimpanan data dan juga mempermudah dalam proses pembuatan laporan. Dengan demikian sistem komputerisasi sangat penting dalam hal menghasilkan pengolahan data terperinci dan akurat untuk memudahkan dalam pengolahan data bagi perusahaan. CV. Clever Kids merupakan suatu perusahaan yang bergerak dibidang penjualan.Dalam pengolahan data CV. Clever Kids masih menjalankan administrasi secara manual mengakibatkan sering terjadi kesalahan dalam pencatatan data dikarenakan tidak adanya data surat jalan, tidak adanya data retur, tidak adanya data stok barang terubdate, dan minimnya data laporan barang. Tujuan dari penelitian ini pertama data yang berkaitan dengan penjualan dapat disimpan dengan baik dengan menggunakan sistem yang terkomputerisasi. Kedua mempermudah dalam penemuan data penjualan yang diperlukan, sehingga data penjualan yang diharapkan dapat dicari secara cepat dan tidak memakan waktu. Ketiga menjaga agar informasi yang ciptakan dapat lebih akurat. Keempat pimpinan mudah dalam memantau penjualan barang yang ada diperusahaan.

Sistem adalah "rangkaian dari dua atau lebih komponen-komponen yang saling berhubungan, yang berinteraksi untuk mencapai suatu tujuan.Sebagian besar sistem terdiridari subsistem yang lebih kecil yang mendukung sistem yang lebih besar”. [1]

Informasi (information) adalah data yang telah dikelola dan diproses untuk memberikan arti dan memperbaiki proses pengambilan keputusan. Sebagaimana perannya, pengguna membuat keputusan yang lebih baik sebagai kuantitas dan kualitas dari peningkatan informasi.[1]

Sistem informasi adalah cara-cara yang diorganisasi untuk mengumpulkan, memasukkan, dan mengolah serta menyimpan data, dan cara-cara yang diorganisasi untuk menyimpan, mengelola, mengendalikan, dan melaporkan informasi 
sedemikian rupa sehingga sebuah organisasi dapat mencapai tujuan yang telah ditetapkan. [2]

Penjualan adalah suatu proses berpindahnya suatu hak atas barang atau jasa untuk mendapatkan sumber daya lainnya seperti kas atau janji untuk membayar sesuai dengan harga yang telah disepakati saat perusahaan menjual barang dagangannya maka akan mendapatkan hasil pendapatannya. Jumlah yang dibebankan kepada pembeli untuk dagang yang diserahkan merupakan pendapatan perusahaan yang bersangkutan. Penjualan merupakan aktivitas utama perusahaan. Pendapatan utama perusahaan sangat ditentukan oleh besar kecilnya penjulan.[3]

Analisa berorientasi objek adalah cara baru dalam memikirkan sebuah masalah dengan menggunakan model yang dibuat menurut konsep sekitar dunia nyata. Dasar pembuatan adalah objek, yang merupakan penggabungan antar struktur data dan perilaku dalam sebuah entitas. Analisa berorientasi objek dimulai dengan menyatakan suatu masalah, analisis menggambarkan model situasi dari dunia nyata, menggambarkan sifat yang penting. [4]. Menurut [5] mendefiniskan analisa berorientasi obyek sebagai kebutuhan sistem.

\section{PENELITIAN SEBELUMNYA}

a. Pengembangan aplikasi penjualan cat di UD. Bagja Jaya menggunakan metodologi waterfall. Garut,2015. ISSN: 2302-7339.

Jurnal ini mendeskripsikan bahwa Penelitian menggunakan metode waterfall sangat bagus walaupun memakan waktu yang cukup lama untuk memperbaiki sistem yang terjadi di perusahaan tersebut.

Perbandingannya Jurnal ini memliki banyak kesamaan dengan penelitian,yaitu mempermudah transaksi penjualan, memberikan informasi yang berguna untuk laporan namun jurnal ini menggunakan flowchart berbeda dengan penelitian yang penulis bahas tidak menggunakan flowchart. [6]

b. Rancang Bangun Sistem Informasi Penjualan Barang Di U.D Cendana Depok Townsquare. Jakarta,2011. ISSN: 1979-0767.

Jurnal ini menjelaskan tentang bagaimana menganalisa dan merancang sistem informasi penjualan menggunakan Rapid Application Design (RAD), (OOA), (OOD). Dan (UML).

Perbandingannya mempermudah proses transaksi masih menjadi point yang sama dengan penelitian yang sedang dibahas. [7]

c. Analisis Dan Perancangan Sistem Informasi

Penjualan Berbasis Web Pada UD Cakra

Motor. Jambi, 2017. ISSN: 2528-0082.

Jurnal ini menjelaskan tentang bagaimana menganalisa dan merancang sistem informasi penjualan dan menghasilkan prototipe sistem informasi penjualan. Serta perancangan sistem pada penelitian ini masih mengandalkan metode waterfall walaupun membutuhkan waktu lama lama perbaikan.

Perbandingannya mempermudah proses transaksi dan Pembuatan laporan masih menjadi point yang sama dengan penelitian yang sedang dibahas. [8]

\section{METODE PENELITIAN}

Dalam melakukan penenelitian tentu ada langkah-langkah yang akan dilakukan dari awal sampai akhir penelitian yang dituangkan dalam gambar 1:

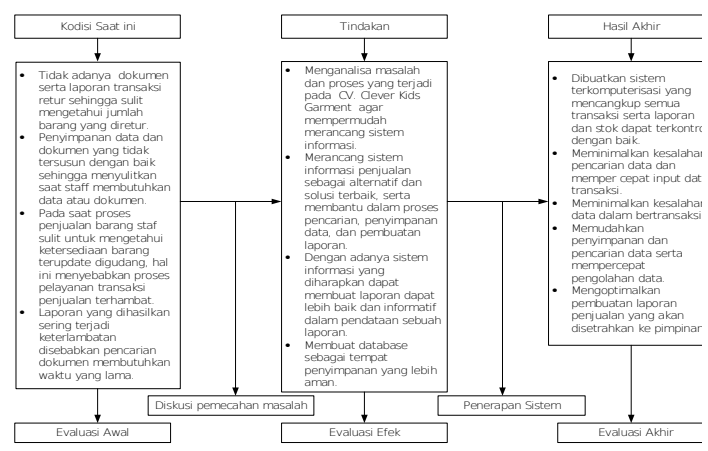

3.1. Metode Pengumpulan Data

1) Pengamatan (Observasi)

Mengadakan pengamatan langsung ke bagian-bagian yang berkaitan dengan sistem penjualan agar data yang dihasilkan lebih lengkap.

2) Wawancara (Interview)

Mengajukan pertanyaan lisan kepada bagian terkait (kantor penjualan) untuk melengkapi data yang diperlukan dalam penelitian.

3) Dokumentasi

Metode penelitian dengan cara mengumpulkan dokumen-dokumen terkait yang menjadi objek penelitian.

4) Metode kepustakaan (Library Research)

Meode penelitian dengan cara mengumpulkan referensi terkait yang menjadi objek penelitian .

\subsection{Metode Analisa Sistem}

Analisa sistem bertujuan untuk mendapatkan persepsi secara keseluruhan tentang sistem yang akan kita kembangkan berdasarkan masukan dari calon pengguna, tujuan utama dari analisa adalah apa yang harus kita lakukan bukan bagaimana 
melakukannya, hasilnya sistem seutuhnya sebagai persiapan menuju tahap perancangan.

\subsection{Metode Perancangan Sistem}

Perancangan sistem untuk mencari strategi pemecahan masalah dan mengembangkan solusi terbaik dari permasalahan itu untuk diimplementasikan.

\section{HASIL DAN PEMBAHASAN}

\subsection{Analisa Proses Bisnis}

"Activity diagram menggambarkan workflow (aliran kerja) atau aktivitas dari sebuah sistem atau proses bisnis atau menu yang ada pada perangkat lunak”. [9]

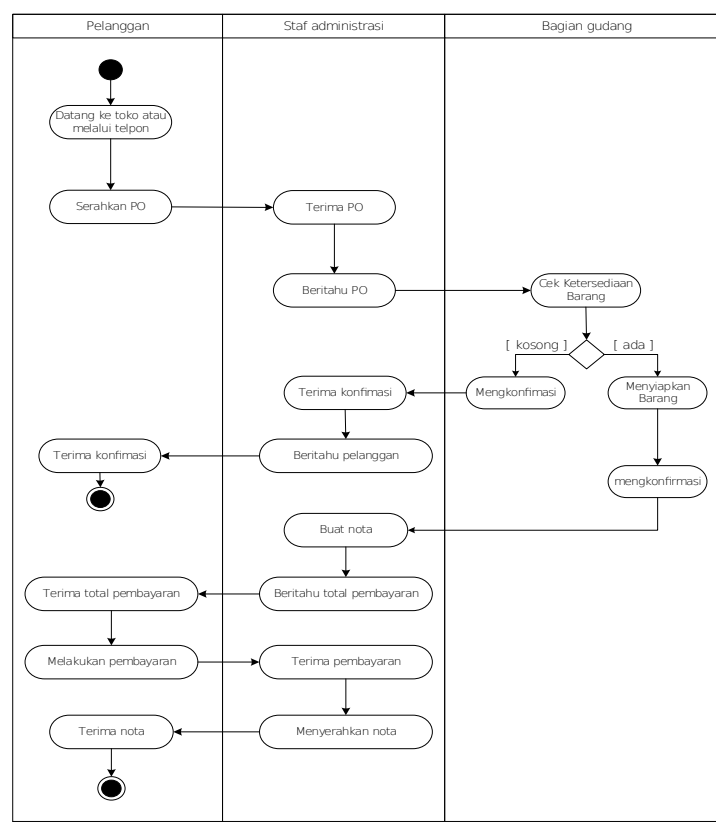

Pelanggan pesan barang yang akan dibeli dengan cara datang ke toko atau via telpon, untuk pesanan via telpon biasanya pelanggan yang sudah menjadi pelangganan tetap dan pembelian dalam jumlah banyak, staf administrasi akan memberitahukan pesanan kepada bagian gudang untuk mengecek barang yang dipesan, apabila stok kosong staff administrasi akan mengkonfirmasi kepada pelanggan bahwa barang yang dipesan kosong. Apabila barang tersedia bagian Gudang akan mempersiapkan barang dan staff administrasi akan mengkonfirmasikan kepada pelanggan untuk pembuatan nota dan pelanggan membayar sesuai total hargal barang yang dipesan kemudian staff administrasi akan memberikan nota sebagai bukti pemesanan dan pembayaran.

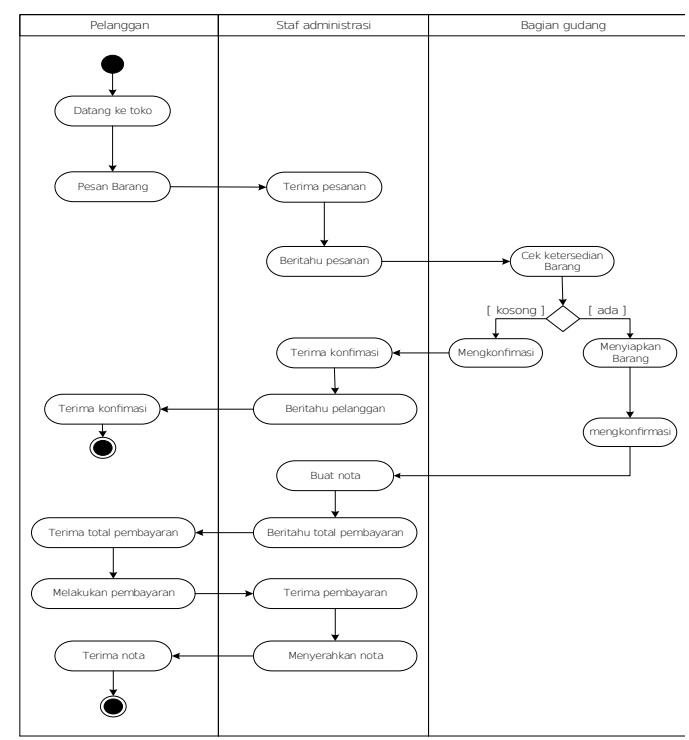

Selain melayani penjualan dalam jumlah banayak dengan pelanggan tetap, CV. Clever Kids melayani penjualan eceran untuk pelanggan yang bukan pelanggan tetap, pelanggan yang akan membeli Barang langsung datang ke toko, lalu memesan barang, staf administrasi akan memberitahukan pesanan kepada bagian gudang untuk mengecek barang yang dipesan, apabila stok kosong staff administrasi akan mengkonfirmasi kepada pelanggan bahwa barang yang dipesan kosong. Apabila Barang tersedia bagian Gudang akan mempersiapkan Barang, pelanggan membayar sesuai jumlah Barang yang dibeli lalu dibuatkan nota, nota diserahkan ke pelanggan bersaaamn dengan barang.

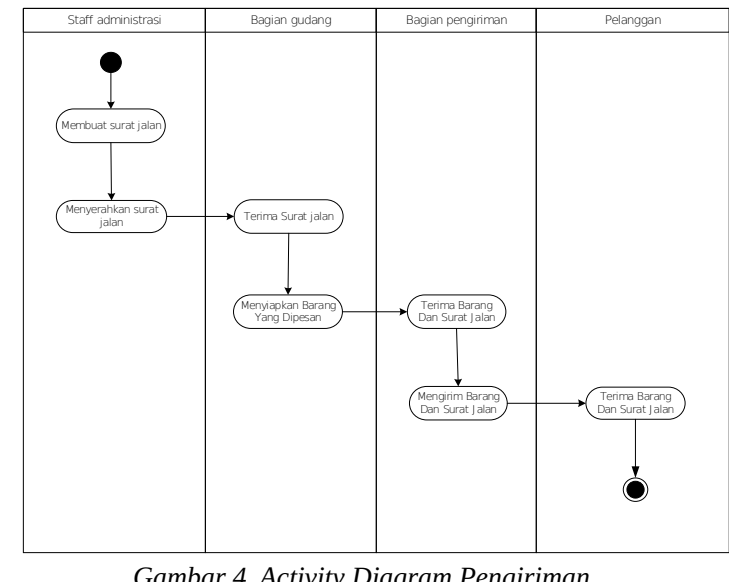

Pengiriman barang hanya untuk pelanggan yang telah menjadi langganan, Setelah pelanggan melakukan proses pembayaran, Staff Administrasi membuatkan Surat Jalan dan memberikannya kepada bagian gudang untuk dipersiapkan 
barangnya. Apabila barang sudah siap untuk dikirim maka bagian gudang akan menyerahkan surat jalan beserta barang ke bagian pengiriman dan bagian pengiriman akan mengirimkan surat jalan dan barang kepada pelanggan.

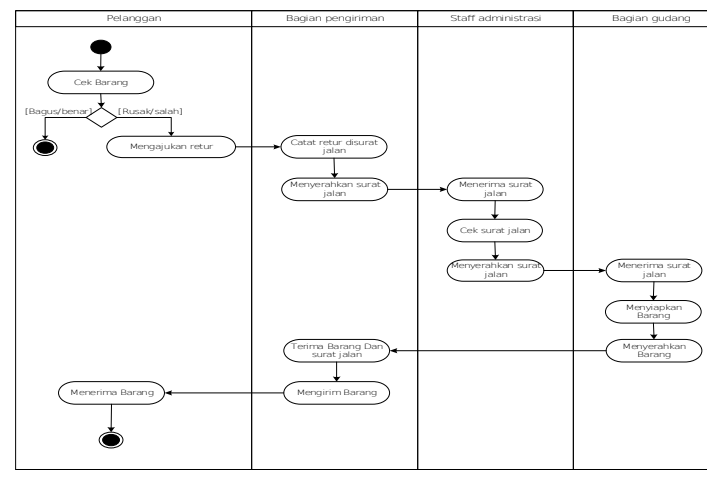

Proses ini dimulai ketika barang sampai dan di cek oleh pelanggan, apabila pelanggan menemukan retur pada barang yang telah dicek maka pelanggaan akan mengajukan surat retur ke bagian pengiriman dan bagian pengiriman memberikan surat jalan yang telah diretur ke staff administrasi serta mengecek barang apa saja yang di retur dan meminta penggantian barang yg diretur ke bagian gudang, setelah bagian gudang menyiapkan penggantian barang yang diretur maka barang akan dikirimkan kembali oleh bagian pemgiriman ke pelanggan.

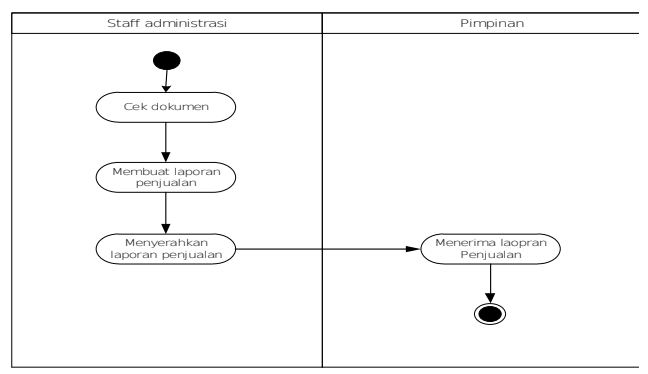

Staf administrasi membuat laporan penjualan barang dan diberikan kepada pemilik untuk didokumentasikan serta untuk memantau aktifitas penjualan pada CV. Clever Kids.

\subsection{Fishbone Diagram Penjualan}

diagram fishbone dapat mengidentifikasi berbagai sebab potensial dari satu efek atau masalah, dan menganalisis masalah tersebut melalui sesi brainstorming. [10].

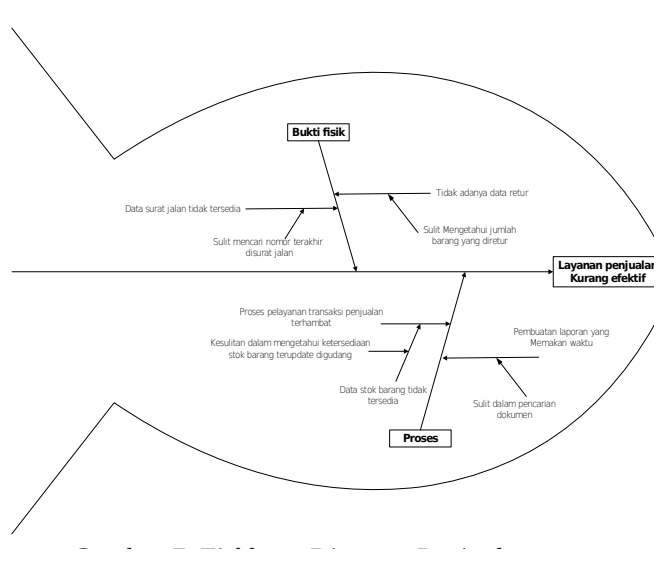

\subsection{Use CaseDiagram Penjualan}

diagram use case merupakan pemodelan untuk kelakuan (behavior) sistem informasi yang akan dibuat. Use case mendeskripsikan sebuah interaksi antara satu atau lebih actor dengan sistem informasi yang akan dibuat” [9]

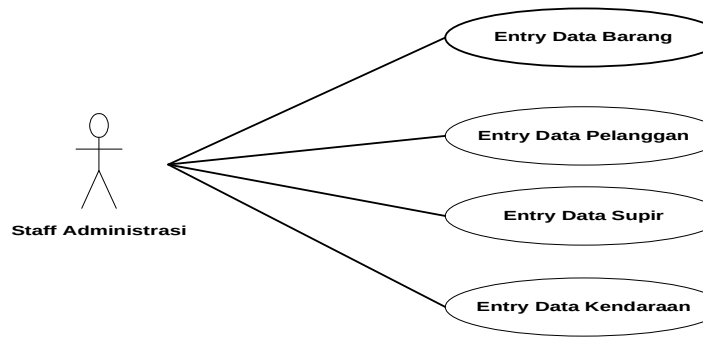

Gambar 8 menjelaskan: Bagian staff administrasi melakukan entry data Barang, Pelanggan, Sopir dan data Kendaraan.

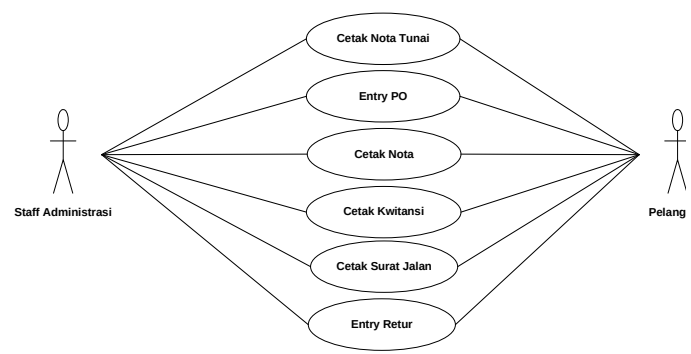

Gambar 9 menjelaskan: Bagian staff administrasi melakukan Cetak Nota Tunai, Entry PO, Cetak Nota Penjualan, Cetak Kwitansi pembayaran, Cetak Surat Jalan Pengiriman dan Entry Barang yag diretur. 


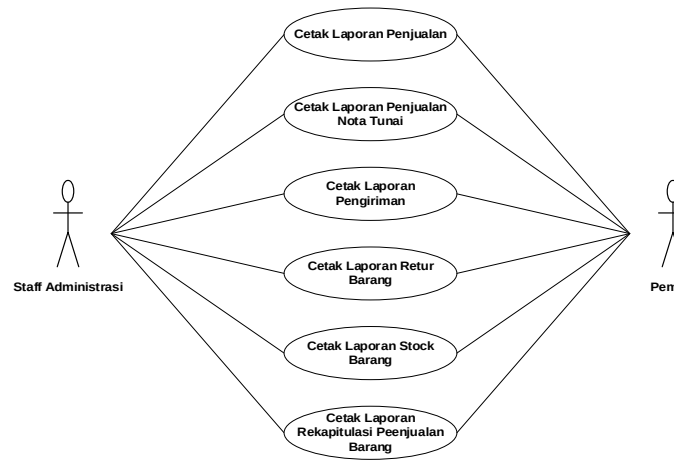

Gambar 10 menjelaskan: Bagian Staff Administrasi mencetak laporan penjualan barang, penjualan nota tunai, pengiriman barang, barang yang diretur, stock barang, dan rekapan barang terlaris.

\subsection{Rancangam Diagram Class}

"Diagram class menggambarkan struktur sistem dari segi pendefinisian kelas-kelas yang akan dibuat untuk membangun sistem”. [9]

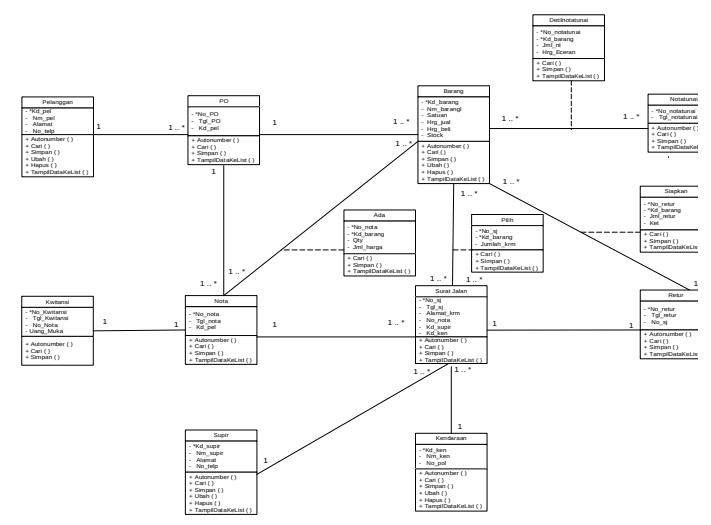

\subsection{User Interface}

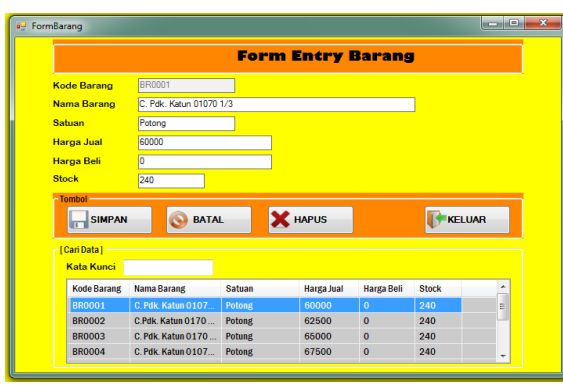

Gambar 12. Form Barang

Gambar 12 menjelaskan: Form Data Barang berisi field-field untuk menginput data barang yang dijual.

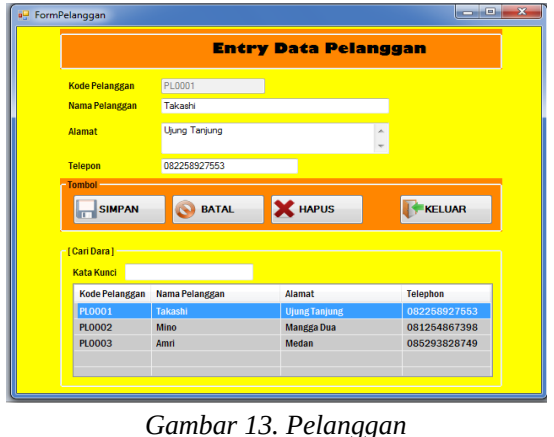

Gambar 13 menjelaskan: Form Data Pelanggan berisi field-field untuk menginput data Pelanggan tetap.

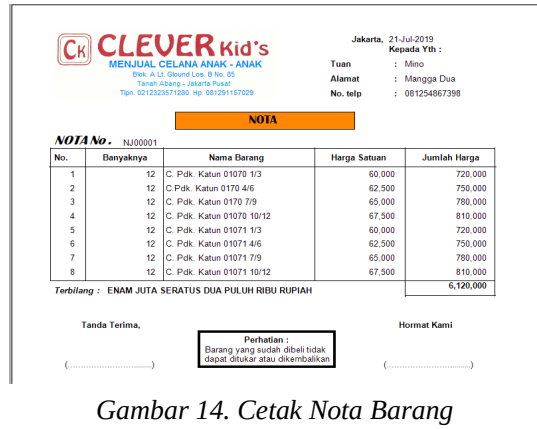

Gambar 14 menjelaskan: Cetakan Nota barang berisi data- data yang akan dicetak.

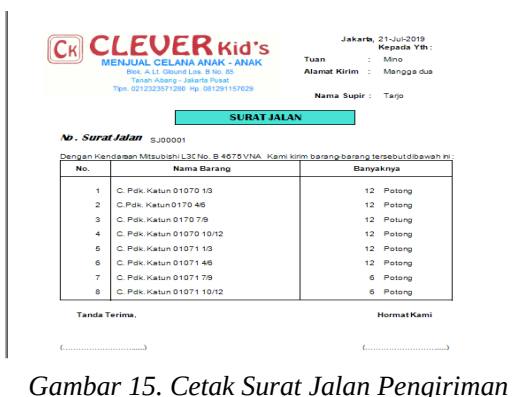

Gambar 15 menjelaskan: Cetakan surat Jalan Pengiriman barang berisi data-data yang akan dicetak.

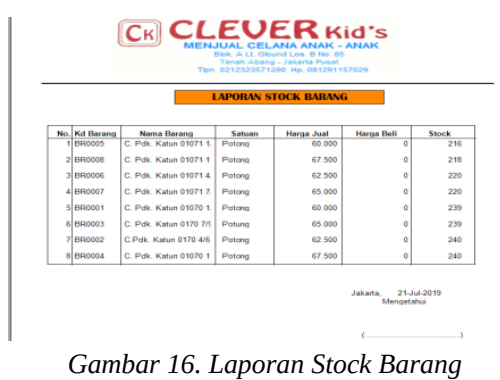

Gambar 16 menjelaskan: Cetakan Laporan Stock barang berisi data- data yang akan dicetak dan dilaporkan kepada pimpinan. 


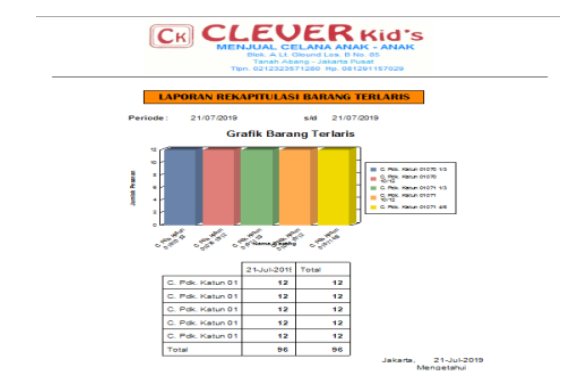

Gambar 17. Laporan Rekapitulasi Barang Terlaris

Gambar 17 menjelaskan: Cetakan Laporan rekap barang yang paling laku berisi data- data yang akan dicetak dan dilaporkan kepada pimpinan.

\subsection{Sequence Diagram}

"Sequence diagram menggambarkan kelakuan objek pada use case dengan mendeskripsikan waktu hidup objek dan message yang dikirim dan diterima antar objek”.[9].

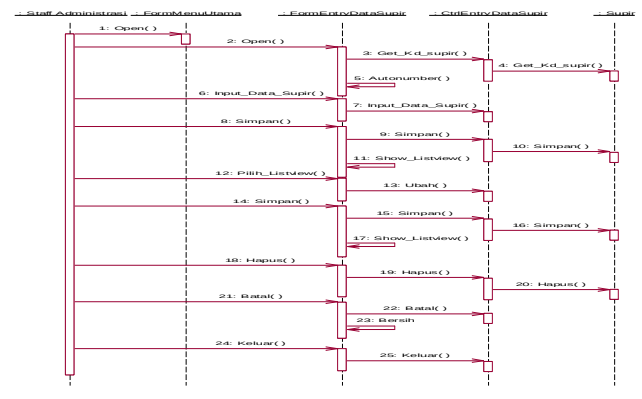

Gambar 18. Sequence Diagram Master Sopir

Gambar 19 adalah sequence cetak nota tunai, diagram yang menjelaskan proses input data nota tunai sopir pada sistem.

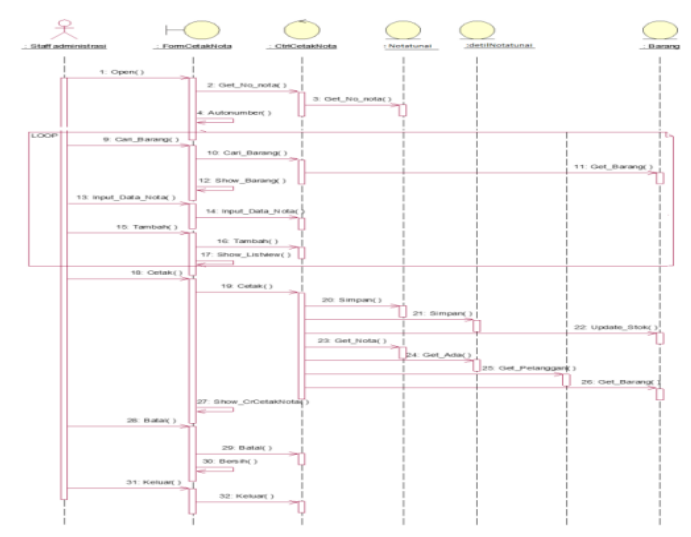

Gambar 19. Sequence Diagram Transaksi Cetak Data Nota tunai

Gambar 20 adalah sequence cetak laporan penjualan, diagram yang menjelaskan proses cetak laporan penjualan pada sistem.

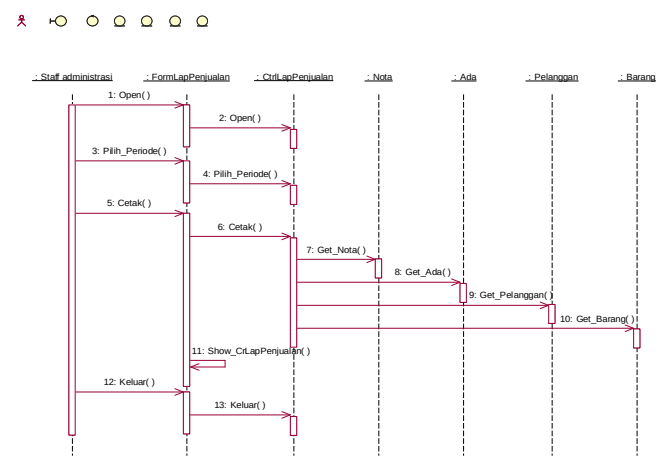

Gambar 20. Sequence Diagram Cetak Laporan Penjualan

\subsection{Korelasi Masalah dan solusi}

Tabel 1. Masalah dan Solusi

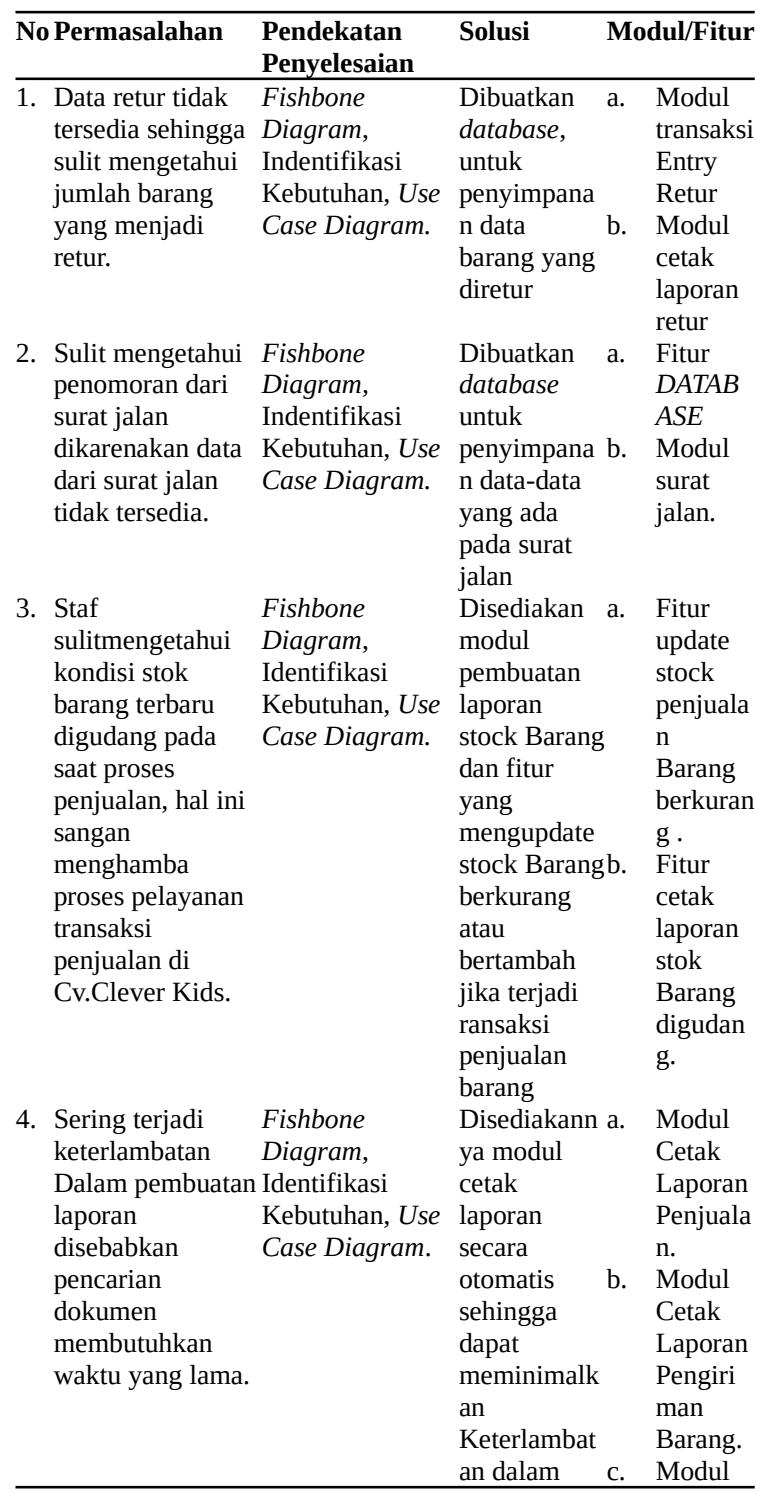




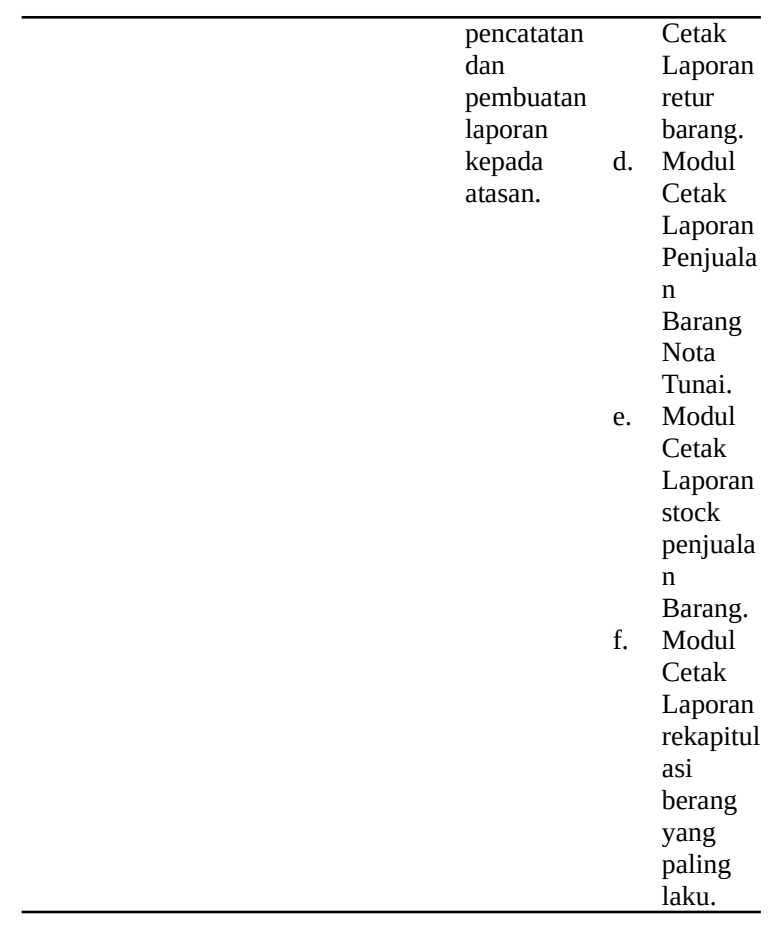

\section{KESIMPULAN}

a. Dengan adanya modul cetak retur dan laporan retur maka kesulitan mengetahui jumlah barang yang diretur dapat diminimalisir

b. Dengan adanya modul cetak surat jalan maka kesulitan mengetahui data surat jalan dapat diminimalisir

c. Dengan sistem yang telah terkomputerisasi, disediakan fitur stock update otomatis pada saat proses penjualan dan disediakan juga modul cetak laporan serta stok barang terbaru sehingga proses penjualan lebih maksimal.

d. Laporan yang dibutuhkan pemilik dengan transaksi penjualan sudah tersedia, sehingga berguna bagi perusahaan.

\section{DAFTAR PUSTAKA}

[1] Romney, Marshall B. dan Steinbart, "Sistem Informasi Akuntansi”, Edisi 13, alihbahasa: Kikin Sakinah Nur Safira dan Novita Puspasari, Salemba Empat, Jakarta, 2015.

[2] Krismiaji, “Sistem Informasi Akuntansi”, Unit Penerbit, Yogyakarta, 2015.

[3] Sumarsono, “ Dasar-dasar Penjulan”, Jakarta: PT.Elex Media Komputindo, 2010.

[4] Whitten, Jeffery L., Lonnie D. Bentley, Kevin C. Dittman, "System Analisis and Design Methods". 6th ed, New York: McGraw-Hill, 2004.

[5] Rosa, A.S. dan Shalahudin M, "Modul Pembelajaran Rekayasa Perangkat Lunak (Terstruktur dan Berorientasi Obyek)”. Bandung: Modula, 2011.
[6] Acep Angga, \& Bunyamin, “Pengembangan aplikasi penjualan dan pembelian bahan bangunan di UD.Bagja Jaya menggunakan metodologi waterfall”, Vol. 12 No. 1, Garut, ISSN: 2302-7339, 2015.

[7] Riandy, Huliyag,\& Subiyanto, “Rancang Bangun Sistem Informasi Penjualan Barang pada U.D Cendana Depok Townsquare”, 4 (1), 1 - 6, Jakarta, ISSN 1979-0767, 2011.

[8] Suma Handaira Putri, \& Herry Mulyono, "Analisis Dan Perancangan Sistem Informasi Penjualan Berbasis Web Pada UD Cakra Motor”, Vol. II, No. 4, Jambi, ISSN. 2528-0082, 2017.

[9] Sukamto, \& Shalahuddin, "Analisa dan Desain Sistem Informasi”, Yogyakarta: Andi, 2013.

[10] Purba, H.H. (2008). Diagram fishbone dari Ishikawa. Retrieved from http://hardipurba.com/2008/09/25/diagram-fishbonedari-ishikawa.html. 